\title{
Udviklingslinjer og forandringer i den aktive arbejdsmarkedspolitik
}

I 2019 er det 25 år siden den aktive arbejdsmarkedspolitik for alvor gjorde sit indtog $i$ Danmark med Nyrups arbejdsmarkedsreformer fra 1994 som startskuddet. Her skete der et skifte eller en forskydning fra en passiv til en aktiv arbejdsmarkedspolitik, hvor pligt til aktivering blev koblet med retten til at modtage ydelser under ledighed. Dette skifte skete ikke blot i en dansk kontekst, men var en del af en større international trend, der også vandt indpas i en række andre lande og som internationalt er kendt som et skifte fra 'welfare' til 'workfare', altså fra forsørgelse til aktivering (Torfing, 2004). Den variant, der opstod i Danmark, fokuserede både på at opkvalificere og motivere arbejdsstyrken (Bredgaard, Jørgensen, Madsen \& Rasmussen, 2017, s. 17-18) og baserede sig derfor både på det, der betegnes som en 'human capital' strategi (hvor styrkelse af kompetencer er i centrum for indsatsen) og en 'workfirst' strategi (hvor styrkelse af motivationen til at tage arbejde er i centrum for indsatsen), mens andre lande fulgte 'work-first' strategien mere stringent (Torfing, 2004). Udover sådan et fokusskifte dannede arbejdsmarkedsreformerne i 1990'erne også rammen om ændringer i selve implementeringen og styringen af området, bl.a. ved en decentralisering af indsatsen og ved nedsættelse af arbejdsmarkedsråd med partsindflydelse (Bredgaard, Jørgensen, Madsen \& Rasmussen, 2017, s. 17).
Når man i dag ser tilbage på udviklingen i den aktive arbejdsmarkedspolitik fra 1994 og frem, så har den på mange områder ændret karakter. Kort ridset op er de vigtigste forandringer formentlig disse: der er sket et sprogligt skifte, hvor termen aktiv arbejdsmarkedspolitik er udskiftet med termen aktiv beskæftigelsespolitik, som bl.a. signalerer vigtigheden af og en mere snæver forståelse af, at beskæftigelse er målet. Indholdsmæssigt er der over tid sket en bevægelse i retning af 'work first' og social disciplinering, hvor uddannelses-og opkvalificeringsaspektet i dag fylder mindre end det gjorde i 1990'erne, og hvor indsatserne i dag er mere præget af samtaler, virksomhedspraktikker m.v., som antages at kunne sikre en hurtigere tilbagevenden til arbejdsmarkedet. Målgruppen er blevet udvidet, sådan at beskæftigelsesindsatsen er rettet mod og rummer alle typer af ledige, fx også sårbare grupper på kanten af arbejdsmarkedet og persongrupper, der tidligere ville være kategoriseret som ikke arbejdsmarkedsparate. I forlængelse heraf er grupper, der traditionelt ville have været omfattet af socialpolitikken blevet indlemmet i beskæftigelsesindsatsen, og socialpolitikken som selvstændigt politikområde er blevet mindre betydningsfuldt. Samtidig er der sket store forandringer i styringen og organiseringen af området, eksempelvis at det tostrengede system, hvor staten var ansvarlig for forsikrede dagpengemodtagere og kom- 
munerne for ikke forsikrede kontanthjælpsmodtagere, er erstattet med ét enstrenget kommunalt system, hvor a-kasserne dog er medspillere i forhold til visse dele af indsatsen for forsikrede dagpengemodtagere. Dette er blot for at nævne nogle få forandringer, men der er mange flere.

Selv om det der i dag betegnes som den aktive beskæftigelsespolitik har undergået mange forandringer siden 1994, så udvikler feltet sig fortsat, og der sker forandringer, som i nogle tilfælde kan forstås som en tilbagevenden til tidligere prioriteringer $i$ politikken og i andre tilfælde som nybrud, hvor der kommer nye forståelser og fokusområder. Temanummeret her rummer 3 artikler og 1 kronik, der alle på forskellig vis beskæftiger sig med udviklingslinjer, forandringer og nybrud i den aktive arbejdsmarkedspolitik i Danmark. Artikel 1 og 2 samt kronikken har det til fælles, at de alle tre kredser omkring problemstillinger, der knytter an til socialpolitikkens indlemmelse i arbejdsmarkedspolitikken, og de forholder sig derfor på forskellig vis til udviklingen i forståelser, prioriteringer og indsatser over for nogle af de grupper af ledige borgere, der tidligere er blevet forstået som værende en del af det socialpolitiske system, men som i dag også skal rummes i den aktive beskæftigelsespolitik. Det gælder eksempelvis de svageste kontanthjælpsmodtagere (i artikel 1 og i kronikken) og førtidspensionisterne (i artikel 2). Artikel 3 beskæftiger sig derimod med kommunale variationer i brugen af uddannelsesaktivering over for forsikrede ledige dagpengemodtagere og kredser derfor om, hvorvidt der er ved at ske en tilbagevending til 'human-capital' strategien i nogle dele af beskæftigelsesindsatsen. I det følgende beskriver vi kort indholdet og pointerne i disse bidrag.

Artikel 1 af Flemming Larsen og Niklas Andersen med titlen 'Fra socialpolitik til beskæftigelsespolitik - er beskæftigelse for alle?' tager afsæt i det faktum, at stort set alle offentligt forsørgede i dag har ret og pligt til en aktiv beskæftigelsesindsats, men stiller i artiklen spørgsmålet, om det er muligt at forfølge denne strategi for de mest udsatte grupper af ledige, som ofte har mange andre udfordringer end blot manglende beskæftigelse. Artiklen har to fokusområder. Først laves en historisk analyse af, hvordan den kommunale tilgang til uddannelses- og kontanthjælpsmodtagere har udviklet sig de sidste 20 år baseret på unikke longitudinelle spørgeskemadata, suppleret med kvalitative data. Dernæst diskuteres kommunernes aktuelle udfordringer og dilemmaer, når de tilrettelægger beskæftigelsesindsatsen over for en stadigt mere broget målgruppe, hvor målsætningen for alle er beskæftigelse. Med det kvantitative materiale viser Larsen og Andersen, at den kommunale tilgang har bevæget sig fra omkring årtusindeskiftet at være forankret i et rationale omkring social integration og social sikring og over til et socialt disciplinerende rationale i de senere undersøgelser fra 2008 og 2017. Det flugter fint med, at dette rationale også er blevet skærpet fra centralpolitisk hold siden årtusindeskiftet. Forfatterne konkluderer dog også, at der i den seneste undersøgelse fra 2017 lader til at være en opbremsning i hvor dominerende disciplineringstankegangen er, og der ser ud til at indfinde sig nogle nye forståelser af, at indsatserne i højere grad skal være helhedsorienterede og i højere grad tage afsæt i de lediges problematikker. Dette bekræftes af de kvalitative data. Det mere ensidige fokus på social disciplinering som vejen til beskæftigelse synes derfor at være brudt eller i hvert fald mindre entydigt end tidligere, og de kommunale forvaltninger lader til at være blevet mere opmærksomme på, at beskæftigelsesmålsætningen er svær at nå for visse grupper af offentligt forsørgede borgere. Der er dog ikke tale om en tilbagevenden til tidligere tiders mere socialpolitiske tænkning. 
Artikel 2 af Finn Amby, Sisse Shaldemose og Anders Bøggild Christensen med titlen 'Førtidspension fra kompensationstanke til udviklingsfokus' analyserer, hvordan førtidspensionsområdet over tid har bevæget sig fra at være et klassisk socialpolitisk indsatsområde til at blive indlemmet som en del af arbejdsmarkedspolitikken. Artiklen, der bygger på en dokumentanalyse af kommissionsrapporter, bemærkningen til lovforslag, høringssvar mv., udpeger reformen fra 2003 som det tidspunkt, hvor bruddet med den hidtidige praksis på området for alvor sætter sig igennem. Den grundlæggende idé om, at førtidspension tildeles som kompensation for tabt arbejdsevne, erstattes nu af et fokus på udviklingen af, hvad der måtte være tilbage af mulig arbejdsevne. Ændringen italesættes som et skift fra fokus på barrierer til fokus på ressourcer og muligheder og knyttes til en diskurs om medborgerskab. Artiklens forfattere erkender, at dette fokusskift for nogle borgere kan have positive effekter i form af styrket arbejdsidentitet og medborgerskab. Forfatterne understreger dog, at medaljen har en bagside i form af forringede livsomstændigheder og samfundsmæssig marginalisering for en stor gruppe mennesker. Samtidig gør forfatterne opmærksomme på, at det politiske sporskifte på førtidspensionsområdet illustrerer en generel trend, hvor grænsen mellem personer i og uden for arbejdsstyrken bliver mere flydende, da store grupper, som tidligere ville have figureret som stående uden for arbejdsmarkedet, nu tvinges til at stå til rådighed for en beskæftigelsesrettet indsats.

Kronikken af Mikkel Morgen med titlen 'Arbejdet som middel, mennesket som mål - eller omvendt?' sætter de seneste årtiers beskæftigelsesorientering af socialpolitikken under kritisk lup og spørger til, om lønarbejdet så er blevet det middel til et bedre liv for udsatte borgere, som man håbede på fra politisk hold? Det korte svar er nej, hvor
Morgen igennem kronikken argumenterer for, hvordan beskæftigelsesfeltet i hans optik ikke er tilstrækkeligt gearet til at arbejde med socialpolitikkens genstandsfelt (de udsatte borgere). Ligeledes argumenterer han for, at beskæftigelsesfeltet mangler at indholdsbestemme det arbejde, der kan tænkes at hjælpe udsatte borgere til et bedre liv. Systemet synes i Morgens optik at bygge på en præmis om, at alt arbejde er sundt, og får man et job, så skal alle andre problemer og udfordringer nok ordne sig, men spørgsmålet er, om arbejde er godt for alle, og om alt arbejde nødvendigvis er godt? Afslutningsvist argumenterer Morgen for, at beskæftigelsessystemet burde have et bedre blik for arbejdets mangfoldighed, arbejdets subjektive mening og læringspotentiale, hvis arbejde skal være målet for udsatte borgere. Her trækker han på indsigter fra arbejdslivsforskningen og voksenpædagogikken, som han mener er relevante perspektiver at inddrage på beskæftigelsesområdet.

Som nævnt før har artikel 3 af Mads Peter Klindt og Rasmus Ravn en anden vinkel på temaet om udvikling og forandring i den aktive arbejdsmarkedspolitik. Bidraget bærer titlen 'Den rådne banan er human kapital' og analyserer kommunernes brug af uddannelse i beskæftigelsesindsatsen overfor forsikrede ledige. Artiklens afsæt er, at den aktive arbejdsmarkedspolitik i Danmark i 00'erne gradvist har bevæget sig væk fra en human kapital-strategi, dvs. væk fra et fokus på at opkvalificere arbejdsstyrken, som politikken ellers var forankret $i$, da den opstod $i$ 90'erne. En beskæftigelsesreform i 2015 åbnede dog mulighed for igen at give visse dele af den ledige population et uddannelsesløft (de forsikrede ledige). På et generelt plan er brugen af uddannelse dog fortsat lav, men der kan observeres store lokale variationer mellem kommunerne. Noget tyder derfor på, at nogle kommuner er vendt tilbage til en 'human-capital' strategi, mens andre har 
fastholdt en 'work-first' strategi. Derfor undersøger Klindt og Ravn, på baggrund af et kvantitativt datasæt fra Jobindsats.dk med data fra 2016, hvad der kan forklare variationerne i omfanget af kommunernes brug af uddannelse. De opstiller tre hypoteser, som de forfølger gennem artiklen. Den første hypotese (funktionel forklaring) går på, at de kommunale variationer kan skyldes, at der er forskel på kommunernes arbejdsmarkedsrelaterede udfordringer og behov. Den anden hypotese (politisk forklaring) tilsiger, at de kommunale variationer kan skyldes forskelligheder i politiske prioriteringer, hvor kommuner med rødt flertal vil være mere uddannelsesvenlige end kommuner med blåt flertal. Den tredje og sidste hypotese (økonomisk forklaring) tilsiger, at økonomisk trængte kommuner vil fravælge uddannelsesaktivering, fordi det er en dyr aktiveringsform. Klindt og Ravn finder, at der er størst statistisk opbakning til de første to hypoteser og konkluderer dermed, at kommuner med en stor andel af ufaglærte samt kommuner med røde borgmestre er mest tilbøjelige til at anvende uddannelsesaktivering over for forsikrede ledige. De bemærker endvidere, at brugen af uddannelse er størst i en række af de kommuner, der udgør den såkaldte 'rådne banan', og de diskuterer derfor afslutningsvist, hvorfor 'human-capital' strategien trives bedst der. En af de mulige forklaringer, som forfatterne giver, er, at flere af disse kommuner er pionerer ift. at etablere tværgående partnerskaber mellem erhvervs-, beskæftigelses- og uddannelsesområderne $\mathrm{i}$ kommunen og regionen.

Nummeret rummer også to artikler uden for tema.

Artikel 4 'Hvad blev der af arbejderklassen? Lønmodtagerens klassebevidsthed ud fra produktionsforholdene' er forfattet af Emmett Caraker og repræsenter en videreudvikling af den klassiske diskussion om klassetilhørsforhold og klassebevidsthed. Artiklen består dels af en diskussion af de klassiske bidrag til denne diskussion fra Karl Marx og E. P. Thomson, som repræsenterer henholdsvis en strukturel og processuel klasseteori til André Gorz og Ulrich Becks problematisering af klassebegrebets relevans i det senmoderne samfund. Desuden refereres der til nyere empiriske studier af den danske klassestruktur og -bevidsthed, som stiller spørgsmålstegn ved Gortz' og Becks teser. Med denne diskussion som afsæt leverer Caraker en empirisk analyse baseret på interviews med i alt 53 lønmodtagere foretaget i 2015. På baggrund af dette empiriske materiale konkluderes det, at hovedparten af de interviewede mener, at dagens Danmark er et klassesamfund i den forstand, at der fortsat eksisterer forskellige klasser i samfundet. Analysen viser imidlertid, at klasse forstås bredt, idet der opereres med en middelklasse, en overklasse og en underklasse. Flertallet af de interviewede opfatter sig som tilhørende middelklassen og kun et fåtal anvender termen arbejderklasse, når de skal beskrive deres sociale position. Dette betyder ikke, at klassesamfundet afskrives, eller at der er tale om en individualiseret bevidsthed som eksempelvis Beck hævder. Dog viser empirien, at erkendelsen af at samfundet er opdelt i klasser primært kobles til indkomst og formue og ikke til magt- og kontrolformer på arbejdspladsniveau, som en klassisk marxistisk analyse lægger op til. Ikke desto mindre konkluderer artiklen, at den marxistiske klasseteori er alt andet end forældet og opfordrer til, at der arbejdes videre med at udvikle en typologi for lønmodtagernes klassebevidsthed, deres forståelser af relationerne mellem klasseinteresser og politiske partier og analyser af deres samfundssyn mere generelt.

Artikel 5, som udgør nummerets sidste artikel, har titlen 'Lønpræmie for lønmodtagere dækket af en overenskomst? Danmark som case', og den er forfattet af Flemming Ibsen, Jacob R. Holm og Stine Rasmussen. 
Den undersøger de lønmæssige gevinster, der er forbundet med fagforeningsmedlemsskab og de afledte effekter af en høj organisationsprocent. Danmark er valgt som case. Artiklen indledes med en gennemgang af den eksisterende forskning på området, som primært omhandler USA og England. Disse studier viser ret entydigt, at der for den enkelte lønmodtager er en lønmæssig gevinst forbundet med et fagforeningsmedlemsskab. Spørgsmålet er, om en lignende tendens kan konstateres for Danmarks vedkommende. Artiklens udgangspunkt er, at det danske arbejdsmarked adskiller sig markant fra eksempelvis det amerikanske og det engelske, i og med at danske overenskomster dækker såvel lønmodtagere, der er medlem af en fagforening som lønmodtagere, der ikke er, de såkaldte 'free-riders'. I stedet for at rette fokus mod de enkelte lønmodtagere undersøger artiklen derfor, hvordan de kollektive overenskomster påvirker løndannelsen. Artiklen, der bygger på et omfattende statistisk materiale omhandlende løn- og organisationsforholdene på det private arbejdsmarked, er den første danske undersøgelse, der har dette udgangspunkt. På baggrund af den empiriske analyse konkluderer artiklen, at der er en lille lønmæssig effekt ved at være medlem af en fagforening og kan således konstatere, at den effekt, som blev konstateret i de udenlandske undersøgelser, også gælder for Danmarks vedkommende. Mere interessant er det imidlertid, at analysen konkluderer, at de kollektive overenskomster, som er omdrejningspunktet i Den Danske Model, bidrager til en mere solidarisk lønpolitik, idet løngevinsten er højest for det lavtlønnede og lavtuddannede arbejde, hvorimod de højtlønnede og højtuddannede vidensarbejdere har et mindre negativt udbytte af fagforeningsmedlemsskabet.

Rigtig god loeselyst.

Stine Rasmussen, Ida Juul \&

Agnete Meldgaard Hansen

\section{REFERENCER}

Bredgaard, T., Jørgensen, H., Madsen, P. K. \& Rasmussen, S. (2017). Dansk arbejdsmarkedspolitik. 2. udgave. København: Jurist- og Økonomforbundets Forlag.

Torfing, J. (2004). Diskursive forhandlingsnetværk i aktiveringspolitikken. Politica, 36(2), 143-163. 


\section{Tak til vore bedømmere}

Et tidsskrift som vores er stærkt afhængig af den hjælp, vi får fra vores mange bedømmere, som vurderer og kommenterer de artikler vi modtager.

Vi skal hermed fremføre en stor tak til alle de bedømmere, der har bidraget til tidsskriftet i 2018

Agnete Meldgaard Hansen

Anette Eklund Hansen

Anne Mette Ødegård

Ann-Katrine Bønnelykke Miranda

Bente Halkier

Charlotte Bloch

Christina Haandbæk Schmidt

Ernst Schraube

Frank Meier

Hanna Barbara Rasmussen

Hanne Mogensen

Jakob Krause-Jensen

Jens Arnholtz

Johnny Dyreborg

John Mathias Gulløv

Justine Grønbæk Pors

Karin Højbjerg

Karsten Albæk
Karen Sjørup

Lene Teglhus Kauffmann

Marianne Høyen

Merete Monrad

Michael Pedersen

Morten Kyed

Nanna Jordt Jørgensen

Niels Christian Mossfeldt Nickelsen

Olaf Rieper

Per Kongshøj Madsen

Pernille Bertelsen

Rasmus Praestmann Hansen

Rikke Thomsen

Søren Voxted

Thim Prætorius

Verner Denvall

Vibeke Andersen 